\title{
Relasi gigi subjek maloklusi kelas I Angle dengan variasi tooth size discrepancy pasca perawatan ortodonti tanpa pencabutan menggunakan alat cekat
}

\author{
Pratama Rizkiriandri Hanivo $^{1^{*}}$, Avi Laviana ${ }^{1}$, Iwa R. Sunaryo ${ }^{1}$ \\ ${ }^{1}$ Departemen Ortodonti, Fakultas Kedokteran Gigi, Universitas Padjadjaran, Indonesia \\ *Korespondensi: email: pratama14001@unpad.ac.id
}

\begin{abstract}
ABSTRAK
Pendahuluan: Ukuran gigi merupakan salah satu faktor penting dalam mencapai tujuan akhir perawatan ortodonti yaitu mencapai estetik dan keseimbangan fungsional yang baik. Tooth size discrepancy dapat menjadi faktor penyebab dari terjadinya maloklusi yang mengakibatkan overbite dan overjet yang tidak ideal. Tujuan penelitian adalah melihat relasi overbite, overjet, dan gigi molar I sebelum dan sesudah perawatan ortodonti tanpa pencabutan menggunakan alat cekat. Metode: Jenis penelitian deskriptif, dilakukan pada 40 sampel model studi pasien yang memiliki oklusi kelas I Angle. Terdapat 3 kelompok variasi ukuran gigi yang dilihat dari rasio Bolton totalnya. Hasil: Kelompok variasi ukuran gigi pada pasien maloklusi kelas I Angle dengan rasio Bolton total normal pada akhir perawatan menggambarkan nilai overbite dengan sebagian besar mencapai ideal, rata-rata overjet terkecil dengan sebagian besar mencapai ideal, dan relasi molar hubungan kelas I Angle sangat sedikit deviasi mesiooklusi. Pasien dengan rasio Bolton total dibawah normal menggambarkan nilai rata-rata overbite terkecil, rata-rata overjet terbesar dengan sebagian besar mencapai ideal, dan relasi molar sedikit deviasi ke mesiooklusi. Pasien dengan rasio Bolton total diatas normal menggambarkan ratarata overbite terbesar dengan sebagian besar mencapai ideal dan relasi molar sedikit deviasi ke distooklusi. Simpulan: Relasi gigi pada akhir perawatan ortodonti tanpa pencabutan menggunakan alat cekat dipengaruhi oleh variasi tooth size discrepancy pada pasien dengan maloklusi kelas I Angle.
\end{abstract}

Kata kunci: Diskrepansi ukuran gigi, rasio Bolton total, overbite, overjet, relasi molar

\section{Description of tooth relation in non-extraction Angle class I malocclusion subject with tooth size discrepancy variation post fixed orthodontic treatment}

\begin{abstract}
Introduction: Tooth size is one of the common factors to achieve final orthodontic treatment that have good aesthetic and balanced dental functional. Tooth size discrepancies can become causative factor of malocclusion that effects overbite and overjet. The purpose of this research is to investigate the description of overbite, overjet, and first molar relation before and after orthodontic fixed treatment. Method: Research method was conducted using descriptive technique from 40 sample of study models that have class I Angle relation. There are 3 tooth size variation groups that classified from their total Bolton ratio value. Result: Patients with class I Angle malocclusion with normal total Bolton ratio value at the end of the orthodontic treatment described ideal overbite value, smallest overjet value which is most of them reach ideal relation, and molar relation non-significantly deviated to mesioocclusion. Patients with below normal total Bolton ratio described the smallest overbite value and highest overjet value with most of them reach ideal relation, and molar relation deviated to mesiooclusion. Patients with above normal total Bolton ratio described the highest overbite value with most of them reach ideal relation and molar relation deviated to distoocclusion. Conclusion: Description of tooth relation in post nonextraction fixed orthodontic treatment is affected by their tooth size discrepancy variation for patient with class I Angle malocclusion.
\end{abstract}

Keywords: Tooth size discrepancies, total Bolton ratio, overbite, overjet, molar relation 


\section{PENDAHULUAN}

Tujuan akhir pasien dalam menjalani perawatan ortodonti adalah untuk kepentingan estetik dan mendapatkan keseimbangan fungsional yang baik. Tujuan tersebut dapat dicapai dengan memperhatikan hubungan gigi-gigi saat beroklusi yang akan mempengaruhi hasil akhir perawatan seperti overbite, overjet, kesesuaian lengkung gigi, dan inklinasi gigi antara rahang atas dengan rahang bawah. ${ }^{1-3}$ Oklusi mencapai keadaan yang normal atau ideal jika susunan gigi dalam lengkung rahang teratur serta terdapat hubungan yang harmonis antar gigi; antar gigi-gigi atas dengan bawah; antar gigi dengan tulang rahang, kranium, otot sekitarnya; curve spee normal; kontak oklusal bonjol mesiobukal molar pertama maksila berada di bukal groove molar pertama mandibula; dan bonjol distobukal molar pertama maksila berada di embrasure antara molar pertama dan kedua mandibula. ${ }^{6,12}$

Suatu bentuk penyimpangan oklusi sebagai variasi biologis normal akan mengakibatkan maloklusi. Penyimpangan tersebut berupa ciriciri maloklusi yang jumlah dan macamnya sangat bervariasi baik pada tiap-tiap individu maupun sekelompok populasi. ${ }^{6}$ Salah satu penyebab terjadinya maloklusi adalah ketidaksesuaian ukuran mesiodistal gigi terhadap lengkung rahang. Relasi gigi dengan ukuran mesiodistal rahang atas besar sedangkan ukuran mesiodistal gigi rahang bawah kecil, tidak mungkin mendapatkan 6 kunci oklusi yang ideal. Keadaan ini disebut dengan tooth size discrepancy (TSD) dan dapat menjadi masalah pada saat menentukan rencana perawatan ortodonti serta pada saat mencapai hasil akhir perawatan ortodonti. ${ }^{10,11}$

Penelitian mengenai ketidaksesuaian ukuran mesiodistal gigi dalam hubungannya dengan perawatan maloklusi diteliti oleh Bolton pada tahun 1958. Bolton mengembangkan 2 rasio untuk memperkirakan ukuran mesiodistal gigi normal dengan menghitung jumlah lebar mesiodistal gigi anterior dan total dari rahang bawah terhadap rahang atas yang dikenal sebagai rasio Bolton anterior dan rasio Bolton total. Rasio Bolton anterior normal yang dijadikan standar untuk perbandingan ukuran mesiodistal gigi adalah $77,2 \% \pm 1,65$ dan untuk rasio Bolton total sebesar $91,3 \% \pm 1,91 .^{3,5}$ Hasil penghitungan rasio Bolton yang semakin besar dari normal, menunjukkan bahwa ukuran gigi rahang bawah lebih besar dan ukuran gigi rahang atas normal. Semakin kecil persentase rasio Bolton maka ukuran gigi rahang bawah normal dan ukuran gigi rahang atas semakin besar. ${ }^{3}$ Hubungan signifikan antara rasio Bolton dan overjet secara statistik ditemukan yaitu apabila nilai rasio Bolton lebih kecil dari normal, walau tanpa tindakan tambahan untuk kompensasinya, maka akan diperoleh nilai overjet dan overbite yang besar pada tahap akhir perawatan ortodonti. Hal tersebut disebabkan karena ukuran gigi-gigi rahang atas dan rahang bawah merupakan faktor mekanis pengendali overjet dan overbite ketika kurva oklusal rahang atas dan rahang bawah beroklusi. ${ }^{4}$ Tujuan penelitian ini adalah untuk dapat menentukan relasi overbite, overjet, dan gigi molar pertama pada pasien maloklusi kelas I Angle dengan rasio Bolton total normal, diatas normal, dan dibawah normal pada akhir perawatan ortodonti menggunakan alat cekat.

\section{METODE}

Jenis penelitian yang digunakan dalam penelitian ini bersifat deskriptif. Pemilihan sampel dilakukan dengan metode purposive sampling terhadap seluruh pasien dengan hubungan Kelas I Angle di Klinik PPDGS Ortodonti RSGM Universitas Padjadjaran pada periode Januari 2015 - Desember 2017 yang telah selesai dilakukan perawatan ortodonti tanpa pencabutan menggunakan alat cekat. Data yang diperoleh merupakan data sekunder.

Alat dan bahan yang digunakan dalam penelitian ini adalah model rahang atas dan bawah pasien yang sesuai dengan kriteria inklusi, jangka yang kedua ujungnya tajam, jangka sorong digital, penggaris, alat tulis, dan kalkulator. Prosedur dalam penelitian ini terdiri dari tiga tahap, yaitu tahap persiapan pembuatan surat-surat perizinan untuk dilakukannya penelitian, kemudian tahap pelaksanaan dengan memilih dan menyeleksi sampel sesuai dengan kriteria, menghitung lebar mesiodistal 6 gigi anterior RA dan RB serta 12 gigi tetap RA dan $\mathrm{RB}$, menghitung rasio Bolton total yang kemudian dikelompokkan berdasarkan indeks rasio Bolton totalnya [RBT dibawah indeks normal $(<89,39 \%)$, RBT indeks normal $(89,39-93,21 \%)$ dan RBT diatas indeks normal $(>93,21 \%)]$. Setelah dilakukan pengelompokkan tahap selanjutnya adalah menghitung dan menentukan overbite, overjet, serta relasi gigi molar pertama dan mencatat 
hasil perhitungan. Terakhir dilakukan tahap evaluasi untuk rekap data ulang dan analisis data.

Data yang didapatkan dari hasil penelitian dikumpulkan, dicatat, diolah dan dianalisis menggunakan analisis data deskriptif kemudian disajikan dalam bentuk tabel. Tiap-tiap variabel dihitung nilai rata-rata (mean), simpangan baku, dan persentase untuk setiap kelompok. Penelitian ini telah mendapatkan pembebasan etik dari Komite Etik Penelitian Kesehatan Universitas Padjadjaran dengan nomor: 52/UN6.C.10/PN/2018.

\section{HASIL}

Penelitian ini dilakukan dengan mengelompokkan sampel berdasarkan kelompok variasi ukuran gigi yang dilihat dari rasio Bolton totalnya pada 40 model studi pasien dengan maloklusi kelas I Angle. Hasil penelitian didapatkan dari 40 sampel yang memenuhi kriteria dan tercatat pada waktu penelitian bulan Januari sampai dengan Februari 2018. Sampel tersebut diperoleh dari model studi pasien yang telah selesai dilakukan perawatan ortodonti menggunakan alat cekat di klinik PPDGS Ortodonti RSGM-FKG Unpad dalam periode Januari 2015 - Desember 2017. Distribusi sampel pada model studi pasien maloklusi kelas I Angle yang dilakukan perawatan ortodonti menggunakan alat cekat berdasarkan jenis kelamin dapat dilihat pada Tabel 1.

Tabel 1 Distribusi Sampel pada Model Studi Pasien Maloklusi Kelas I Angle yang Dilakukan Perawatan Ortodonti Menggunakan Alat Cekat Berdasarkan Jenis Kelamin

\begin{tabular}{ccc}
\hline Jenis Kelamin & Frekuensi & Persentase \\
\hline Perempuan & 34 & $85,0 \%$ \\
Laki-Laki & 6 & $15,0 \%$ \\
\hline Total & $\mathbf{4 0}$ & $\mathbf{1 0 0} \%$ \\
\hline
\end{tabular}

Tabel 1 menunjukkan bahwa data distribusi sampel pada model studi pasien maloklusi kelas I Angle yang dilakukan perawatan ortodonti menggunakan alat cekat berdasarkan jenis kelamin paling banyak terjadi pada perempuan, yaitu sebanyak 34 orang $(85,0 \%)$ dan laki-laki sebanyak 6 orang $(15,0 \%)$. Distribusi sampel pada model studi pasien maloklusi kelas I Angle yang dilakukan perawatan ortodonti menggunakan alat cekat berdasarkan kelompok variasi ukuran gigi yang dilihat dari rasio Bolton totalnya dapat dilihat pada Tabel 2 .

Tabel 2 Distribusi Sampel pada Model Studi Pasien Maloklusi Kelas I Angle yang Dilakukan Perawatan

Ortodonti Menggunakan Alat Cekat Berdasarkan Kelompok Variasi Ukuran Gigi yang Dilihat dari

Rasio Bolton Totalnya

\begin{tabular}{ccc}
\hline \hline Kelompok Variasi Ukuran Gigi & N & Persentase \\
\hline $\begin{array}{c}\text { Rasio Bolton Total Normal } \\
\text { Rasio Bolton Total Dibawah } \\
\quad \text { Normal }\end{array}$ & 22 & $55,0 \%$ \\
Rasio Bolton Total Diatas Normal & 71 & $17,5 \%$ \\
\hline Total & $\mathbf{4 0}$ & $\mathbf{1 0 0} \%$ \\
\hline
\end{tabular}

Tabel 2 menunjukkan bahwa jumlah sampel yang ditemukan pada kelompok dengan rasio Bolton total normal sebanyak 22 orang (55,0\%), rasio Bolton total dibawah normal sebanyak 7 orang $(17,50 \%)$, rasio Bolton total diatas normal sebanyak 11 orang $(27,50 \%)$ dari total 40 sampel. Berdasarkan hal tersebut, jumlah sampel terbanyak terdapat pada kelompok dengan rasio Bolton total normal (55,0\%). Jumlah sampel paling sedikit terdapat pada kelompok rasio Bolton total dibawah normal (17,5\%). Tabel 3 memperlihatkan rata-rata rasio Bolton anterior dan rasio Bolton total pada setiap kelompok variasi ukuran gigi.

Tabel 3 Rata-Rata Rasio Bolton Anterior dan Rasio Bolton Total pada Setiap Kelompok Variasi Ukuran Gigi yang Dilihat dari Rasio Bolton Totalnya

\begin{tabular}{cccc}
\hline & & \multicolumn{2}{c}{$\begin{array}{c}\text { Rata-Rata \% } \\
\text { (Simpangan Baku) }\end{array}$} \\
$\begin{array}{c}\text { Kelompok Variasi } \\
\text { Ukuran Gigi }\end{array}$ & $\mathbf{N}$ & $\begin{array}{c}\text { Rasio } \\
\text { Bolton } \\
\text { Anterior }\end{array}$ & $\begin{array}{c}\text { Rasio } \\
\text { Bolton } \\
\text { Total }\end{array}$ \\
\hline \hline $\begin{array}{c}\text { Rasio Bolton Total } \\
\text { Normal }\end{array}$ & 22 & $79,33(2,70)$ & $91,74(0,98)$ \\
$\begin{array}{c}\text { Rasio Bolton Total } \\
\text { Dibawah Normal }\end{array}$ & 7 & $75,89(2,70)$ & $86,88(1,81)$ \\
$\begin{array}{c}\text { Rasio Bolton Total } \\
\text { Diatas Normal }\end{array}$ & 11 & $82,25(3,21)$ & $94,75(1,90)$ \\
\hline Total & $\mathbf{4 0}$ & $\mathbf{7 9 , 5 3 ( 3 , 4 9 )}$ & $\begin{array}{c}\mathbf{9 1 , 7 1} \\
\mathbf{( 2 , 9 5 )}\end{array}$ \\
\hline
\end{tabular}

Tabel 3 menunjukkan rata-rata rasio anterior Bolton pada seluruh sampel sebesar 79,53\% $\pm 3,49$ dan rasio total Bolton sebesar $91,71 \% \pm 2,95$. Rata-rata rasio Bolton anterior terkecil terdapat pada kelompok rasio Bolton total dibawah normal $(75,89 \pm 2,70)$ dan yang terbesar terdapat pada kelompok rasio Bolton total diatas normal $(82,25 \pm 3,21)$. Tabel 4 memperlihatkan 
rata-rata kelebihan ukuran lebar mesiodistal 12 gigi RA dan RB pada setiap kelompok variasi ukuran gigi yang dilihat dari rasio Bolton totalnya.

Tabel 4 menunjukkan pada kelompok rasio Bolton total dibawah normal dapat dilihat adanya kelebihan ukuran pada 12 gigi rahang atas sebesar $5,06 \pm 2,15 \mathrm{~mm}$ dari seharusnya dan pada kelompok rasio Bolton total diatas normal dapat dilihat adanya kelebihan ukuran pada 12 gigi rahang bawah sebesar 3,36 $\pm 1,75 \mathrm{~mm}$ dari seharusnya. Rata-rata overbite dan overjet sebelum dan sesudah perawatan ortodonti menggunakan alat cekat pada setiap kelompok variasi ukuran gigi yang dilihat dari rasio Bolton totalnya dapat dilihat pada Tabel 5 .

Tabel 4 Rata-Rata Kelebihan Ukuran Lebar Mesiodistal 12 Gigi RA dan RB pada Setiap Kelompok Variasi Ukuran Gigi yang Dilihat dari Rasio Bolton totalnya

\begin{tabular}{cccc}
\hline Kelompok Variasi Ukuran Gigi & N & \multicolumn{2}{c}{$\begin{array}{c}\text { Rata-Rata Kelebihan Ukuran Lebar Mesiodistal Gigi (mm) } \\
\text { (Simpangan Baku) }\end{array}$} \\
\hline & & Maks “12” & Mand “12” \\
\hline Rasio Bolton Total Dibawah Normal & 7 & $5,06(2,15)$ & $3,36(1,75)$ \\
Rasio Bolton Total Diatas Normal & 11 & & \\
\hline
\end{tabular}

Tabel 5Rata-Rata Kelebihan Ukuran Lebar Mesiodistal 12

Gigi RA dan RB pada Setiap Kelompok Variasi Ukuran Gigi yang Dilihat dari Rasio Bolton totalnya

\begin{tabular}{cccccc}
\hline & & \multicolumn{2}{c}{$\begin{array}{c}\text { Rata-Rata Overbite } \\
\text { (Simpangan Baku) (mm) }\end{array}$} & \multicolumn{2}{c}{$\begin{array}{c}\text { Rata-Rata Overjet } \\
\text { (Simpangan Baku) (mm) }\end{array}$} \\
\cline { 3 - 6 } Kelompok Variasi Ukuran Gigi & $\mathbf{N}$ & $\begin{array}{c}\text { Sebelum } \\
\text { Perawatan }\end{array}$ & $\begin{array}{c}\text { Sesudah } \\
\text { Perawatan }\end{array}$ & $\begin{array}{c}\text { Sebelum } \\
\text { Perawatan }\end{array}$ & $\begin{array}{c}\text { Sesudah } \\
\text { Perawatan }\end{array}$ \\
\hline Rasio Bolton Total Normal & 22 & $3,02(1,34)$ & $1,78(1,03)$ & $2,61(1,35)$ & $1,11(0,64)$ \\
Rasio Bolton Total Dibawah Normal & 7 & $2,14(2,34)$ & $1,74(0,45)$ & $2,92(2,69)$ & $1,35(0,46)$ \\
Rasio Bolton Total Diatas Normal & 11 & $2,77(2,13)$ & $1,90(0,88)$ & $2,86(1,36)$ & $1,27(0,64)$ \\
\hline Total & $\mathbf{4 0}$ & $\mathbf{2 , 8 0 ( 1 , 7 6 )}$ & $\mathbf{1 , 8 1 ( 0 , 9 0 )}$ & $\mathbf{2 , 7 3 ( 1 , 6 1 )}$ & $\mathbf{1 , 2 0}(\mathbf{0 , 6 0})$ \\
\hline
\end{tabular}

Tabel 5. menunjukkan gambaran rata-rata overbite sebelum perawatan pada seluruh sampel

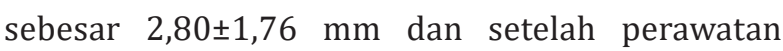
sebesar $1,81 \pm 0,9 \mathrm{~mm}$. Rata-rata overjet sebelum perawatan pada seluruh sampel sebesar 2,73 $\pm 1,61$ mm dan setelah perawatan sebesar $1,20 \pm 0,6 \mathrm{~mm}$. Rata-rata overbite sebelum perawatan dengan nilai terkecil terdapat pada kelompok rasio Bolton total dibawah normal $(2,14 \pm 2,34 \mathrm{~mm})$ dan terbesar pada kelompok rasio Bolton total normal $(3,02 \pm 1,34$ $\mathrm{mm}$ ) .

Rata-rata overbite sesudah perawatan dengan nilai terkecil terdapat pada kelompok dengan rasio Bolton total dibawah normal $(1,74 \pm 0,45 \mathrm{~mm})$ dan terbesar pada kelompok rasio Bolton total diatas normal $(1,90 \pm 0,88 \mathrm{~mm})$. Rata-rata overjet sebelum perawatan dengan nilai terkecil terdapat pada kelompok rasio Bolton total normal $(2,61 \pm 1,35$ $\mathrm{mm}$ ) dan terbesar pada kelompok rasio Bolton total dibawah normal $(2,92 \pm 2,69 \mathrm{~mm})$. Rata-rata overjet sesudah perawatan dengan nilai terkecil terdapat pada kelompok dengan rasio Bolton total normal $(1,11 \pm 0,64 \mathrm{~mm})$ dan terbesar pada kelompok rasio Bolton total diatas normal $(1,27 \pm 0,64 \mathrm{~mm})$.

Jumlah pasien dengan overbite sebelum dan sesudah perawatan ortodonti menggunakan alat cekat pada setiap kelompok variasi rasio Bolton total dapat dilihat pada Tabel 6. Tabel 7 menunjukkan bahwa mayoritas pasien yang dilakukan perawatan ortodonti menggunakan alat cekat memiliki overjet yang diatas ideal (55\%).

Kelompok variasi ukuran gigi yang memiliki persentase overjet ideal sebelum perawatan tertinggi adalah kelompok dengan rasio Bolton total normal (45,45\%)Persentase keberhasilan mencapai overjet yang ideal setelah perawatan pada seluruh sampel adalah sebesar 65\% Persentase keberhasilan mencapai overjet ideal setelah perawatan paling tinggi ditemukan pada kelompok dengan rasio Bolton total dibawah normal $(71,43 \%)$ 
Tabel 6. Jumlah pasien dengan Overbite Sebelum dan Sesudah Perawatan Ortodonti Menggunakan Alat Cekat pada Setiap Kelompok Variasi Rasio Bolton Total

\begin{tabular}{|c|c|c|c|c|c|c|c|c|}
\hline \multirow{2}{*}{$\begin{array}{c}\text { Kelompok Variasi Ukuran } \\
\text { Gigi }\end{array}$} & \multicolumn{4}{|c|}{$\begin{array}{c}\text { Overbite } \\
\text { Sebelum Perawatan }\end{array}$} & \multicolumn{4}{|c|}{ Overbite Sesudah Perawatan } \\
\hline & $\begin{array}{c}<0 \\
\mathrm{n}(\%)\end{array}$ & $\begin{array}{c}0-2 \\
\text { n }(\%)\end{array}$ & $\begin{array}{c}>2 \\
\text { n (\%) }\end{array}$ & $\begin{array}{c}\mathrm{N} \\
(\%) \\
\end{array}$ & $\begin{array}{c}<0 \\
\text { n }(\%) \\
\end{array}$ & $\begin{array}{c}0-2 \\
\text { n (\%) }\end{array}$ & $\begin{array}{c}>2 \\
\text { n }(\%)\end{array}$ & $\begin{array}{c}\mathrm{N} \\
(\%)\end{array}$ \\
\hline Rasio Bolton Total Normal & $\begin{array}{c}0 \\
(0,00)\end{array}$ & $\begin{array}{c}6 \\
(27,27)\end{array}$ & $\begin{array}{c}16 \\
(72,73)\end{array}$ & $22(100)$ & $\begin{array}{c}0 \\
(0,00)\end{array}$ & $\begin{array}{c}14 \\
(63,64)\end{array}$ & $\begin{array}{c}8 \\
(36,36)\end{array}$ & $\begin{array}{c}22 \\
(100)\end{array}$ \\
\hline $\begin{array}{c}\text { Rasio Bolton Total Dibawah } \\
\text { Normal }\end{array}$ & $\begin{array}{c}2 \\
(28,57)\end{array}$ & $\begin{array}{c}1 \\
(14,29)\end{array}$ & $\begin{array}{c}4 \\
(57,14)\end{array}$ & $7(100)$ & $\begin{array}{c}0 \\
(0,00)\end{array}$ & $\begin{array}{c}5 \\
(71,43)\end{array}$ & $\begin{array}{c}2 \\
(28,57)\end{array}$ & $\begin{array}{c}7 \\
(100)\end{array}$ \\
\hline $\begin{array}{c}\text { Rasio Bolton Total Diatas } \\
\text { Normal }\end{array}$ & $\begin{array}{c}1 \\
(9,09)\end{array}$ & $\begin{array}{c}3 \\
(27,27)\end{array}$ & $\begin{array}{c}7 \\
(63,64)\end{array}$ & $11(100)$ & $\begin{array}{c}0 \\
(0,00)\end{array}$ & $\begin{array}{c}7 \\
(63,64)\end{array}$ & $\begin{array}{c}4 \\
(36,36)\end{array}$ & $\begin{array}{c}11 \\
(100)\end{array}$ \\
\hline Total & $\begin{array}{c}3 \\
(7,50)\end{array}$ & $10(25,00)$ & $\begin{array}{c}27 \\
(67,50)\end{array}$ & $40(100)$ & $\begin{array}{c}0 \\
(0,00)\end{array}$ & $\begin{array}{c}26 \\
(65,00)\end{array}$ & $\begin{array}{c}14 \\
(35,00)\end{array}$ & $\begin{array}{c}40 \\
(100)\end{array}$ \\
\hline
\end{tabular}

Tabel 7. Jumlah pasien dengan Overjet Seelum dan Sesudah Perawatan Ortodonti Menggunakan Alat Cekat pada Setiap Kelompok Variasi Rasio Bolton Total

\begin{tabular}{|c|c|c|c|c|c|c|c|c|}
\hline \multirow{2}{*}{$\begin{array}{c}\text { Kelompok Variasi Ukuran } \\
\text { Gigi }\end{array}$} & \multicolumn{4}{|c|}{$\begin{array}{c}\text { Overjet } \\
\text { Sebelum Perawatan }\end{array}$} & \multicolumn{3}{|c|}{$\begin{array}{c}\text { Overjet Sesudah } \\
\text { Perawatan }\end{array}$} & \multirow[b]{2}{*}{$\begin{array}{c}N \\
(\%)\end{array}$} \\
\hline & $\begin{array}{c}<1 \\
\text { n }(\%)\end{array}$ & $\begin{array}{c}1-2 \\
\text { n }(\%)\end{array}$ & $\begin{array}{c}>2 \\
\text { n }(\%)\end{array}$ & $\begin{array}{c}\mathrm{N} \\
(\%)\end{array}$ & $\begin{array}{c}<1 \\
\text { n }(\%)\end{array}$ & $\begin{array}{c}1-2 \\
\text { n (\%) }\end{array}$ & $\begin{array}{c}>2 \\
\text { n }(\%)\end{array}$ & \\
\hline Rasio Bolton Total Normal & $\begin{array}{c}1 \\
(4,55)\end{array}$ & $\begin{array}{c}10 \\
(45,45)\end{array}$ & $\begin{array}{c}11 \\
(50,00)\end{array}$ & $\begin{array}{c}22 \\
(100)\end{array}$ & $\begin{array}{c}7 \\
(31,81)\end{array}$ & $\begin{array}{c}14 \\
(63,64)\end{array}$ & $\begin{array}{c}1 \\
(4,55)\end{array}$ & $\begin{array}{c}22 \\
(100)\end{array}$ \\
\hline $\begin{array}{l}\text { Rasio Bolton Total } \\
\text { Dibawah Normal }\end{array}$ & $\begin{array}{c}1 \\
(14,29)\end{array}$ & $\begin{array}{c}2 \\
(28,57)\end{array}$ & $\begin{array}{c}4 \\
(57,14)\end{array}$ & $7(100)$ & $\begin{array}{c}2 \\
(28,57)\end{array}$ & $\begin{array}{c}5 \\
(71,43)\end{array}$ & $\begin{array}{c}0 \\
(0,00)\end{array}$ & $\begin{array}{c}7 \\
(100)\end{array}$ \\
\hline $\begin{array}{c}\text { Rasio Bolton Total Diatas } \\
\text { Normal }\end{array}$ & $\begin{array}{c}0 \\
(0,00)\end{array}$ & $\begin{array}{c}4 \\
(36,36)\end{array}$ & $\begin{array}{c}7 \\
(63,64)\end{array}$ & $\begin{array}{c}11 \\
(100)\end{array}$ & $\begin{array}{c}2 \\
(18,18)\end{array}$ & $\begin{array}{c}7 \\
(63,64)\end{array}$ & $\begin{array}{c}2 \\
(18,18)\end{array}$ & $\begin{array}{c}11 \\
(100)\end{array}$ \\
\hline Total & $\begin{array}{c}2 \\
(5,00)\end{array}$ & $16(40,00)$ & $\begin{array}{c}22 \\
(55,00)\end{array}$ & $\begin{array}{c}40 \\
(100)\end{array}$ & $\begin{array}{c}11 \\
(27,50)\end{array}$ & $\begin{array}{c}26 \\
(65,00)\end{array}$ & $\begin{array}{c}3 \\
(7,50)\end{array}$ & $\begin{array}{c}40 \\
(100)\end{array}$ \\
\hline
\end{tabular}

Tabel 8. Rata-Rata Relasi Molar Sebelum dan Sesudah Perawatan Ortodonti Menggunakan Alat Cekat pada Setiap Kelompok

\begin{tabular}{|c|c|c|c|c|c|}
\hline \multirow{3}{*}{$\begin{array}{c}\text { Kelompok Variasi Ukuran } \\
\text { Gigi }\end{array}$} & & \multicolumn{4}{|c|}{ Variasi Rasio Bolton Total } \\
\hline & $\mathbf{N}$ & \multicolumn{2}{|c|}{$\begin{array}{c}\text { Rata-Rata Relasi Molar Sebelum } \\
\text { Perawatan } \\
\text { (Simpangan Baku) }(\mathrm{mm})\end{array}$} & \multicolumn{2}{|c|}{$\begin{array}{l}\text { Rata-Rata Relasi Molar Sesudah } \\
\text { Perawatan } \\
\text { (Simpangan Baku) }(\mathrm{mm})\end{array}$} \\
\hline & & Kanan & Kiri & Kanan & Kiri \\
\hline $\begin{array}{c}\text { Rasio Bolton Total } \\
\text { Normal }\end{array}$ & 22 & $-0,50(1,24)$ & $-0,99(1,21)$ & $-0.01(0,74)$ & $-0,08(0,43)$ \\
\hline $\begin{array}{c}\text { Rasio Bolton Total } \\
\text { Dibawah Normal }\end{array}$ & 7 & $0,08(0,89)$ & $-1,56(2,38)$ & $0,01(0,53)$ & $-0,37(0,48)$ \\
\hline $\begin{array}{c}\text { Rasio Bolton Total Diatas } \\
\text { Normal }\end{array}$ & 11 & $-0,40(1,88)$ & $-0.05(1,68)$ & $0,33(1,01)$ & $0,12(1,02)$ \\
\hline Total & 40 & $-0,73(1,38)$ & $-0,83(1,63)$ & $0,08(0,79)$ & $-0,11(0,25)$ \\
\hline
\end{tabular}

Tabel 6 menunjukkan bahwa mayoritas pasien yang dilakukan perawatan ortodonti menggunakan alat cekat memiliki overbite yang diatas ideal $(67,50 \%)$. Persentase keberhasilan mencapai overbite yang ideal setelah perawatan pada seluruh sampel adalah sebesar 65\%. Persentase keberhasilan mencapai overbite ideal setelah perawatan paling tinggi ditemukan pada kelompok dengan rasio Bolton total dibawah normal $(71,43 \%)$. Tabel 7 memperlihatkan jumlah pasien dengan overjet sebelum dan sesudah perawatan ortodonti menggunakan alat cekat pada setiap kelompok variasi rasio Bolton total.. Tabel 8 
memperlihatkan rata-rata relasi molar sebelum dan sesudah perawatan ortodonti menggunakan alat cekat pada setiap kelompok variasi rasio Bolton total. Tabel 8 menunjukkan pada kelompok rasio Bolton total normal, pada sebelum dan sesudah perawatan terjadi sedikit deviasi pada relasi gigi molar pertama ke arah kelas III (mesiooklusi) yang ditandai dengan nilai negatif (-). Kelompok rasio Bolton total dibawah normal memperlihatkan relasi gigi molar pertama yang mengalami deviasi ke arah kelas III (mesiooklusi) dan sisi kanan hanya sangat sedikit mengalami deviasi ke arah kelas II (distooklusi) sebesar 0,01 $\mathrm{mm}$ pada sebelum dan sesudah perawatan. Kelompok rasio Bolton diatas normal menunjukkan deviasi ke arah kelas III (mesiooklusi) pada sebelum perawatan dan deviasi ke arah kelas II (distooklusi) yang ditandai dengan nilai positif ( + ) pada sesudah perawatan ortodonti menggunakan alat cekat.

\section{PEMBAHASAN}

Penelitian ini bertujuan untuk melihat gambaran relasi gigi pada subjek Kelas I Angle pada berbagi variasi tooth size discrepancy yang dilihat dari rasio Bolton totalnya. Sampel penelitian melibatkan model studi pasien berjenis kelamin laki-laki sebanyak 6 sampel (15\%) dan pasien perempuan sebanyak 34 sampel (85\%) dengan total keseluruhan sampel sebanyak 40 model studi pasien yang kemudian dikelompokan berdasarkan nilai rasio Bolton totalnya yaitu kelompok dengan rasio Bolton total normal (89,39-93,21\%), rasio Bolton total dibawah normal $(<89,39 \%)$, dan rasio Bolton total diatas normal $(>93,21 \%)$. Berdasarkan literatur, dijelaskan bahwa tidak terdapat perbedaan yang signifikan untuk hasil rasio Bolton pada pasien berjenis kelamin laki-laki dengan perempuan. Oleh karena itu, sampel laki-laki dan perempuan tidak dilakukan perlakuan yang berbeda dan sampel dikombinasikan ketika menganalisis data. ${ }^{7,8,9,14}$

Berdasarkan hasil penelitian pada tabel 2 dan 3, diperoleh data bahwa kelompok variasi ukuran gigi dengan jumlah sampel terbanyak adalah pada kelompok rasio Bolton total (RBT) normal sebanyak 22 pasien (55\%) dengan rata-rata RBA sebesar $79,33 \% \pm 2,70$ dan RBT sebesar 91,74\% $\pm 0,98$. Kelompok rasio Bolton total dibawah normal sebanyak 7 pasien $(17,5 \%)$ dengan rata-rata RBA sebesar 75,89\% $\pm 2,70$ dan RBT sebesar 86,88\% $\pm 1,81$.
Kelompok rasio Bolton total diatas normal sebanyak 11 pasien $(27,5 \%)$ dengan rata-rata RBA sebesar $82,25 \% \pm 3,21$ dan RBT sebesar 94,75\% $\pm 1,90$. Hasil ini dapat menjadi suatu kesimpulan bahwa sebagian besar pasien yang dilakukan perawatan ortodonti menggunakan alat cekat memiliki rasio Bolton total dengan indeks normal $(89,39-93,21 \%)$. Hasil penelitian ini sejalan dengan penelitian yang dilakukan oleh Demmajanang dan Erwansyah (2013) yang diketahui bahwa berdasarkan rasio Bolton totalnya (RBT), kelompok dengan jumlah sampel terbanyak adalah pasien dengan indeks Bolton total normal pada pasien ortodonti yang dirawat di RSGMP Universitas Hasanudin sebesar 41,6\% dari total 156 sampel. ${ }^{5}$

Gambaran rata-rata kelebihan ukuran lebar mesiodistal 12 gigi rahang atas dan 12 gigi rahang bawah pada setiap kelompok variasi ukuran gigi yang dilihat dari nilai rasio Bolton totalnya diperlihatkan pada tabel 4. Pada kelompok dengan rasio Bolton total dibawah normal terlihat adanya perbedaan ukuran lebar mesiodistal 12 gigi dimana ukuran gigi atas memiliki ukuran yang lebih besar dan pada kelompok dengan rasio Bolton total diatas normal memiliki ukuran gigi bawah yang lebih besar. Hasil ini sesuai dengan penjelasan Bolton (1958) bahwa bila nilai rasio Bolton yang diperoleh lebih besar dari nilai rata-rata berarti ada kelebihan materi gigi pada rahang bawah, sedangkan bila nilai perbandingan yang diperoleh lebih kecil dari nilai rata-rata berarti ada kelebihan materi gigi pada rahang atas. ${ }^{3,4}$

Tabel 5 menunjukkan rata-rata overbite dan overjet sebelum dan setelah dilakukannya perawatan ortodonti menggunakan alat cekat. Rata-rata overbite sebelum perawatan dengan nilai terkecil terdapat pada kelompok rasio Bolton total dibawah normal dan terbesar pada kelompok rasio Bolton total normal. Rata-rata overbite sesudah perawatan dengan nilai terkecil terdapat pada kelompok rasio Bolton total dibawah normal dan terbesar pada kelompok rasio Bolton total diatas normal.

Hasil ini tidak sesuai dengan pernyataan Moyers bahwa bila rasio Bolton lebih kecil atau dibawah dari normal, tanpa tindakan tambahan untuk mengkompensasinya dapat diperoleh nilai overbite yang besar pada akhir perawatan. Namun, hasil gambaran rata-rata overjet sebelum dan sesudah perawatan sesuai dengan pernyataan dari Moyers dimana nilai overbite sebelum perawatan dan sesudah perawatan terbesar terdapat pada 
kelompok rasio Bolton total dibawah normal. ${ }^{5}$ Apabila ukuran gigi rahang atas lebih besar daripada gigi rahang bawah, maka akan dihasilkan relasi overjet yang lebih besar pada sebelum dan sesudah perawatan dibandingkan dengan rasio Bolton yang normal atau diatas normal.

Perawatan ortodonti menggunakan alat lepasan akan lebih sulit untuk memperbaiki overjet yang sudah besar pada sebelum perawatan karena selain mempertimbangkan overjet, perawatan ortodonti cekat juga harus memperhatikan relasi molar dari oklusi pasien yang akan dihasilkan pada akhir perawatan. ${ }^{5}$ Hasil penelitian menunjukkan overbite dan overjet sampel sebelum perawatan pada tabel 6 dan 7. Data tersebut dapat menyimpulkan bahwa mayoritas pasien yang dilakukan perawatan ortodonti menggunakan alat cekat memiliki overbite lebih dari $2 \mathrm{~mm}(67,50 \%)$ dan overjet lebih dari 2 mm (55\%).

Overbite dan overjet yang tidak ideal dapat berpengaruh terhadap penampilan dari pasien sehingga mempengaruhi psikologis dan interaksi sosialnya. Sebagian besar motivasi pasien dalam melakukan perawatan ortodonti yaitu lebih untuk memperbaiki penampilan (estetik) dibandingkan dengan memperbaiki fungsional. Oleh karena itu, salah satu tantangan terbesar dalam hasil perawatan ortodonti menggunakan alat cekat adalah mencapai overbite dan overjet yang ideal pada akhir perawatan. ${ }^{13}$

Gambaran tingkat keberhasilan mencapai hasil akhir posisi overbite dan overjet yang ideal setelah perawatan ditemukan paling tinggi pada kelompok rasio Bolton total dibawah normal. Hasil ini menggambarkan bahwa kelompok dengan rasio Bolton total $<89,39 \%$ cenderung memiliki tingkat keberhasilan perawatan yang lebih tinggi pada aspek posisi overbite dan overjet dibandingkan dengan kelompok lain. Hal ini juga tidak sejalan dengan pendapat Moyers bahwa bila rasio Bolton lebih kecil atau dibawah dari normal, tanpa tindakan tambahan untuk mengkompensasinya dapat diperoleh nilai overbite dan overjet yang besar pada akhir perawatan. ${ }^{5}$

Klasifikasi maloklusi menurut Angle merupakan sistem klasifikasi yang paling sering digunakan di ilmu kedokteran gigi. Tujuan dari perawatan ortodonti adalah tercapainya oklusi kelas I Angle dan telah disepakati sebagai oklusi yang ideal. Namun, klasifikasi maloklusi Angle memiliki beberapa kekurangan, salah satunya terdapatnya kerancuan hubungan molar yang memungkingkan terjadinya deviasi dari oklusi cusp-fossa molar rahang atas dengan molar rahang bawah. Oklusi cusp-fossa ideal yang dideskripsikan oleh Angle merujuk kepada tidak adanya deviasi $(0 \mathrm{~mm})$ antara hubungan tersebut. Segala bentuk deviasi dari bentuk ideal dihitung pada kedua sisi dalam satuan milimeter. Tanda positif (+) mengindikasikan adanya deviasi ke arah kelas II (distooklusi) dan tanda negatif (-) mengindikasikan ke arah kelas III (mesiooklusi). Oklusi ideal pada sisi kanan dan sisi kiri ditandakan sebagai 'Kelas I $(0,0)$ '. ${ }^{16}$

Data dalam tabel 8, menunjukkan bahwa kelompok dengan rasio Bolton total normal memiliki hubungan molar kelas I Angle yang mengalami deviasi ke arah kelas III pada sebelum dan sesudah perawatan ortodonti. Selain relasi gigi molar, perawatan ortodonti juga harus mempertimbangkan aspek estetik pasien yang dilihat dari relasi overbite dan overjet-nya. Berdasarkan data, sebagian besar pasien yang melakukan perawatan ortodonti memiliki nilai overbite dan overjet tidak ideal pada sebelum perawatan. Untuk dapat mengurangi nilai overbite dan overjet, dilakukan perawatan pada bagian anterior dan akan mempengaruhi hubungan oklusi fossa-cusp dan lengkung gigi pada bagian posterior dari pasien sehingga akan mengalami sedikit deviasi ke arah kelas III karena tidak dilakukan tindakan ekstraksi. ${ }^{5,15}$

Kelompok dengan rasio Bolton total dibawah normal saat sebelum dan sesudah perawatan memiliki hubungan molar kelas I Angle yang mengalami sedikit deviasi ke arah kelas III. Ukuran gigi rahang atas yang lebih besar dari gigi rahang bawah akan mengakibatkan overjet yang besar pada pasien. Semakin besar nilai overjet di anterior, maka dalam perawatan ortodonti akan semakin besar pula pergeseran yang terjadi pada bagian posteriornya. Hal ini mengakibatkan deviasi ke kelas III yang lebih besar pada kelompok RBT dibawah normal dibandingkan dengan kelompok RBT normal., 3,15,16

Kelompok rasio Bolton diatas normal mengalami deviasi di kedua sisi ke arah kelas III pada sebelum perawatan dan deviasi di kedua sisi ke arah kelas II pada setelah perawatan. Ukuran gigi rahang bawah yang lebih besar dari gigi rahang atas akan mengkibatkan overjet yang lebih kecil dibandingkan pada rasio Bolton normal dan dibawah normal. Jika nilai overjet sebelum perawatan lebih 
kecil, maka untuk mencapai overjet yang ideal hanya dilakukan sedikit pergeseran molar ke arah kelas II. Ketika proses perawatan, ukuran gigi bawah yang lebih besar mengakibatkan pergeseran lengkung gigi rahang bawah ke arah posterior sehingga pada gigi molar pertama atas terlihat deviasi ke arah kelas II dibandingkan dengan sebelum perawatan. ${ }^{15,16}$

Hasil penelitian menunjukkan tooth size discrepancy dapat berkontribusi dalam proses menentukan rencana perawatan. Klinisi ortodonti harus menaruh perhatian lebih agar mendapatkan hasil perawatan yang maksimal dalam mencapai overbite, overjet, dan oklusi yang ideal. Segala alternatif ataupun interverensi dari perawatan yang akan dilakukan harus mempertimbangkan hasil dari analisis Bolton untuk mencapai susunan gigi yang ideal misalnya dalam pertimbangan tindakan ekstraksi, slicing, atau stripping sehingga hasil perawatan yang didapatkan akan lebih efisien dan akurat.

\section{SIMPULAN}

Pasien maloklusi kelas I Angle dengan rasio Bolton total normal pada akhir perawatan ortodonti menggunakan alat cekat menggambarkan nilai overbite dengan sebagian besar mencapai ideal, rata-rata overjet terkecil dibandingkan kelompok lain dengan sebagian besar mencapai overjet ideal, dan relasi molar hubungan kelas I Angle dengan sangat sedikit deviasi ke arah kelas III; Pasien maloklusi kelas I Angle dengan rasio Bolton total dibawah normal pada akhir perawatan ortodonti menggunakan alat cekat mempunyai nilai rata-rata overbite terkecil, rata-rata overjet terbesar dengan sebagian besar pasien mencapai overbite dan overjet ideal, dan relasi molar hubungan kelas I Angle dengan sedikit deviasi ke arah kelas III; Pasien maloklusi kelas I Angle dengan rasio Bolton total diatas normal pada akhir perawatan ortodonti menggunakan alat cekat mempunyai nilai rata-rata overbite terbesar dibandingkan kelompok lain dengan sebagian besar overbite dan overjet mencapai ideal, dan relasi molar hubungan kelas I Angle dengan sedikit deviasi ke arah kelas II.

\section{DAFTAR PUSTAKA}

1. Akyalcin S, Dogan S, Dincer B, Erdinc AM, Oncag G. Bolton tooh size discrepancies in skel- etal class I individuals presenting with different dental classifications. Angle Orthodontist. 2006;76(4):637-43.

2. Al-Omari, I., Al-Bitar, Z. \& Hamdan, A. Tooth size discrepancies among Jordanian schoolchildren. Eur J Orthod. 2008;30(5):527-531.

3. Bolton W. Disharmony in tooth size and its relation to analysis and treatment of malocclusion. Angle Orthod. 28;(30):113-130.

4. Budiman, J., Yashadana, E., Sadoso, S., \& Masbirin, P. (2015). Hubungan Rasio Anterior dengan Overjet dan Overbite pada Perawatan Orthodontik. Journal Of Dentistry Indonesia, 4(3), 19 - 25. DOI: $10.14693 /$ jdi.v4i3.756

5. Demmajannang T, Erwansyah E. Gambaran indeks Bolton pada pasien yang dirawat dengan piranti ortodontik lepasan di Rumah Sakit Gigi Mulut Universitas Hasanuddin. Dentofasial. Oktober 2013;12(3):175-182.

6. Irwansyah $\mathrm{M}$, Erwansyah E. Penilaian tingkat keberhasilan perawatan ortodontik dengan piranti lepasan berdasarkan indeks PAR Assessment of success rate of orthodontic treatment using removable appliance based on PAR index. J Dentomax Sci. 2011;10(3):144150. DOI: http://dx.doi.org/10.15562/jdmfs. v10i3.273

7. Hyder M, Mamun M, Hossain M. Tooth size discrepancies among different malocclusions in a Bangladesh orthodontic population. Bangladesh J Orthodon Dent Orthoped. 2012;2(2): 8-17.

8. Johe R. Intermaxillary tooth-size discrepancies in different sexes, malocclusion groups, and ethnicities. Am J Orthod Dentofacial Orthop, 2010;138(5):599-607.

9. Lavelle C. Maxillary and mandibular tooth size in different racial groups and in different occlusal categories. Am J Orthod. 1972;29-37.

10. O'Mahony G, Millett DT, Barry MK, Mclintyre GT, Cronin MS. Tooth size discrepancies in Irish orthodontic patients among different malocclusion groups. Angle Orthod. 2011;81(1):130-3. DOI: 10.2319/050610246.1.

11. Proffit W. Contemporary orthodontics. 5th ed. St. Louis (MO): Mosby. 2012.

12. Rahardj P. Diagnosis Ortodontik. Surabaya: Airlangga University Press.2011

13. Riska. Persepsi masyarakat awam terhadap 
estetika senyum dari pemakaian alat ortodonti cekat dan lepasan, Makassar: FKG Universitas Hassanudin. 2015

14. Strujic M, Milosevic AS, Mestrovic S, Slaj M. Tooth size discrepancy in orthodontic patients among different malocclusion groups.
Eur J Orthod. 584-589. 2009.

15. Sulandjari H. Buku Ajar Ortodonsia I KGO I Fakultas Kedokteran Gigi UGM. Yogyakarta: Yadav D, Rani M, Shailaja A, Anand D. Angle's Molar Classification Revisited. s.l.:The Journal of Indian Orthodontic Society. 2014. 